Est Ag 50 (2015) 493-520

\title{
Repasando Perfectae Caritatis *
}

\author{
Tomás Marcos Martínez, osa \\ Estudio Teológico Agustiniano. Valladolid
}

RESUMEN: La Perfectae caritatis resulta un microcosmos conciliar, reproduce en su interior el encuadre esencial del Vaticano II desde su nacimiento. Las pulsiones para la aparición y despliegue del gran sínodo se zambullen en la actualización de la Iglesia. Y el decreto pretende, como expresa su título, "la adecuada renovación de la vida religiosa". Ambos, concilio y decreto, Iglesia y vida religiosa, destacan pues dos líneas de acción: por un lado, la refacción o el recomienzo; por otro, la adaptación o modernización. El mismo decreto explicitará esta interpretación animando a "una renovación eficaz y una recta acomodación" (PC 4). En este trabajo seguiremos su hilo conductor.

Palabras Clave: Monacato, cenobitismo, carismas, oración, votos, comunidad.

AbSTRACT: Perfectae caritatis is a conciliar microcosm, it repeats inside the essential frame of Vatican II since its birth. The drives for the beginning and deployment of the great synod dive into the updating of the Church. And the decree aims, as said the title, to "the adaptation and renewal of religious life". Both, council and decree, Church and religious life, emphasize two lines of action: first, the renovation or restarting; secondly, the accommodation or modernization. The same decree will specify this interpretation encouraging an "effective renewal and straight adaptation" (PC 4). In this paper we intend to follow this thread.

KEYWORDS: Monasticism, cenobitism, charismas, prayer, vows, community.

* Versión corregida y algo aumentada del artículo homónimo aparecido previamente en I. GonzÁlez Marcos (ed), La vida consagrada: epifanía del amor de Dios en el mundo (XVII Jornadas Agustinianas), Madrid 2015, 133-163. 
La convocatoria del concilio Vaticano II, expresada a menudo por Juan XXIII en sus alocuciones previas al evento, buscaba la renovación y aggiornamento de la vida eclesial ${ }^{1}$. Renovación sugiere volver a ser nuevo, recuperar la frescura de los inicios. Aggiornamento es 'puesta al día', italianismo que invadió todas las lenguas occidentales y asumió solito la descripción del horizonte conciliar, como si hubiera logrado una síntesis redonda. Por su parte, el decreto Perfectae caritatis, en plena torrentera sinodal, invita a los religiosos a ser "signo del reino" evangélico siguiendo lo que "aconsejan nuestros tiempos" (PC 1). Por eso, en vez de "la adecuada renovación" algunos prefieren desdoblar el título: "la adaptación y la renovación de la vida religiosa".

Así pues, refundación y actualización, vuelta a los orígenes e inserción en la modernidad, las dos cosas al tiempo, complementándose y hasta cierto punto corrigiéndose, aunque la esencia originaria prevalezca sobre la inmersión cultural. En el esfuerzo de revitalización promovido por el concilio en absoluto podía quedar al margen la "vida religiosa", una de las instituciones centrales de la Iglesia. El tema sería abordado con pasión: muchos padres conciliares y peritos provenían de dicho estamento, y además la vida consagrada suponía (y supone) un enorme banco de energías de la Iglesia, con activos en todas las áreas posibles: misiones, pastoral, educación, beneficencia, contemplación... un ejército numeroso de ellos y ellas, presente en todas partes, y por sus votos disciplinado, austero y disponible. El resultado de los debates quedó reflejado en dos documentos conciliares: en la constitución Lumen gentium, que englobando los diversos aspectos de la Iglesia ad intra se refirió a "los religiosos" en el capítulo VI (números 43-47); y en el decreto Perfectae caritatis, dedicado específicamente a la vida consagrada. Era la primera vez que un concilio ecuménico abordaba de modo orgánico el tema de la vida religiosa.

Un eje será pues el "retorno constante a las fuentes de toda vida cristiana", la sequela Christi o imitación de Cristo, y matizadamente "a la primigenia inspiración de los institutos" religiosos, al "espíritu de los fundadores" (PC 2); es decir, por un lado vuelta a la Escritura, palabra revelada o norma normans de la fe y vida creyente, y por otro recuperación del carisma fundacional de la vida religiosa, reasentamiento en los fundamentos del monaquismo. Y el segundo eje será "la adaptación a las cam-

${ }^{1}$ Por ejemplo AAS 51, 1959, 65-69; 51, 1959, 498ss; L'Osservatore Romano, 21.II.1960.

${ }^{2}$ Así J.M. TILlaRD, Las grandes leyes de la renovación de la vida religiosa: $\mathrm{VV}$ AA, La adaptación y la renovación de la vida religiosa. Vaticano II, Madrid 1969, 66. 
biadas condiciones de los tiempos" (PC 2), para que la palabra eterna de Dios sea inteligible a los hombres de hoy. En resumen, la renovación implicaría retornar al evangelio y al carisma, fuentes inagotables de la vida religiosa, mientras la adecuación miraría a los signos de los tiempos, las convicciones inalienables de la modernidad. La Perfectae caritatis no supone una reflexión sistemática, una teología completa de la vida religiosa; pero sí un repaso implícito de su historia y esencia.

\section{DUM SUBSTANTIAM HABEAMUS}

Renovar o refundar, podría ser la cuestión. Hasta la brusca aparición en nuestros ambientes de un grupo político nuevo, que a resultas de la grave crisis económica en que estamos y la ira ciudadana subsiguiente pareciera auparse hasta posibilidades de gobierno, nos parecían términos sinónimos, tal vez el segundo dándole un matiz de radicalidad o profundidad, pero sin anular el sentido restaurador fundamental del primero. De modo parecido, una de las últimas controversias sobre el Vaticano II ha girado sobre si fue un concilio de ruptura o de renovación, encontrándose la respuesta en la palabra reforma, esto es, renovación sin ruptura ${ }^{3}$. Renovar, refundar, reformar... En fin, todo coincide en la paradoja de que es necesario un cambio profundo en la vida religiosa para mantener su frescura original en nuestros días, su atractivo irresistible, su poder de irradiación también hoy. Tal ha sido el mérito reconocido al Vaticano II, su impulso dinamizador de la vida cristiana en general, reverdeciéndola desde la mentalidad moderna pero sin perder su raíz original.

En muchos aspectos la teología no puede evitar atollarse en la terminología. El objeto de la fe, Dios y lo trascendente, no ofrece muchas concreciones. Es como avanzar envueltos en la niebla por senderos terrosos con continuos baches y ramificaciones: no se puede estar seguro de la mejor ruta, pero cada paso dirigido por un ramal determinado -el término elegido- parece ir condicionando la meta.

¿Cómo llamar a la llamada vida religiosa? Es una de las dudas que reflejan los borradores iniciales del futuro decreto sobre el tema ${ }^{4}$. El esquema

${ }^{3}$ Benedicto XVI, Alocución a la Curia romana, 22.XII.2005.

${ }^{4}$ Sobre el proceso de redacción, A. Le Bourgeors, Aspecto histórico del decreto: VV AA, La adaptación y la renovación de la vida religiosa. Vaticano II, Madrid 1969, 37-60. 
primero rezaba De statibus perfectionis acquirendae. La expresión "estado de perfección" suscitaba, con razón, bastante rechazo. Denotaba unos aires de grandeza que casaban mal con los humildes orígenes del monaquismo: simplemente retirarse al desierto para orar; al desierto, dejando la pompa y comodidades sociales, para que nada distrajera su recentramiento en Dios. Cierto es que los eremitas pioneros causaron gran sensación, se ponderaba hasta tal punto su desapego hacia la vida terrena que se les consideró dignos sucesores de los admirados mártires, pues su modo de vida expresaba el ideal cristiano al que se debía tender. Pero la vida humana y sus instituciones no son sino limitadas, nada puede aspirar ni por asomo a ningún estado de perfección. Además, la expresión conllevaba un matiz peyorativo de otros estados de vida cristiana, necesariamente menos perfectos por comparación. Con todo, la susodicha expresión ha seguido campando: incluso el título latino del texto -sus dos primeras palabras- la refiere: Perfectae caritatis, "la aspiración a la caridad perfecta". Hubiera sido mejor enardecer el sintagma inverso que mienta "la perfección de la caridad" (LG 39), referida a todos los cristianos en cuanto llamados al carisma superior de la caridad (1Cor 13), en vez de congelar el estereotipo de "caridad perfecta", que implica calidades inferiores de caridad, independientes de su vivencia.

El segundo esquema titubeará entre el título nuevo De religiosis y el anterior De statibus perfectionis, pero el tercero se reafirmó en De religiosis, coincidiendo además con el título del capítulo VI de la Lumen gentium, que correspondía al mismo tema. El cuarto boceto reincidía en el mismo nombre, aunque más perifrásticamente: De accommodata renovatione vitae religiosae. Será el borrador aprobado para la discusión en aula, y que tras las correcciones correspondientes dará lugar al último esquema y texto definitivo, sin variaciones en lo que respecta al título. Es cierto que "vida religiosa" o "religiosos" es igualmente una descripción que podría aplicarse al ideal cristiano y a los cristianos en general, y que por parangón pareciera arrinconar a los demás en una vida menos religiosa. Pero resulta una expresión más neutral que "estado de perfección", por una parte, pues vida religiosa alude a la concentración en lo religioso, no a la condición ontológica de los religiosos. Y por otra parte es la denominación más aceptada popularmente, lo que bien puede compensar cierta imprecisión (como entender el sacerdocio cristiano sólo como sacerdocio jerárquico obviando el sacerdocio común), al fin y al cabo la teología no pretende ser una ciencia exacta.

Expresión paralela a vida religiosa, y tomada como sinónima, será la de "vida consagrada". Esta terminología en torno a la consagración aparece muchas veces en los documentos conciliares (por ejemplo LG 44; 46; 
PC $1 ; 11 ; 14)^{5}$. Consagrar, derivado de sacrum, 'lo apartado' de lo profano, lo santificado, significará 'separar' para Dios, y por extensión 'dedicar' en exclusiva. Así que encierra un inevitable matiz de excelencia, lo que es acercado a lo divino, y en este sentido sería una vuelta a la idea de cierta superioridad. Pero, como en el caso de vida religiosa, se puede argüir que se trataría de una vida dedicada a lo divino, y no una condición de quienes se dedican a ello. Consagrados serían los absortos en Dios, en intención personal y en estructuración colectiva. Otra cosa es que lo consigan, algo imposible por la imperfección humana. El Vaticano II incluye en la vida consagrada a "las religiones [institutos religiosos], las sociedades de vida común sin votos y los institutos seculares" (PC 1). El derecho canónico, siempre más práctico que la teología por (de)formación profesional, ha preferido también esta denominación. Considera el pueblo de Dios en tres apartados: fieles, jerarquía e "institutos de vida consagrada y sociedades de vida apostólica" (libro II, parte III). Dentro de la vida consagrada engloba a institutos religiosos e institutos seculares, ambos comprometidos con los consejos evangélicos, y les asocia las sociedades de vida apostólica por similitud (canon 731). El dicasterio romano del ramo sigue dicha denominación desde 1988 con Juan Pablo II: "Sagrada Congregación para los Institutos de Vida Consagrada y Sociedades de Vida Apostólica"; un poco antes, con Pablo VI en 1967, se denominaba: "Sagrada Congregación para los Religiosos y los Institutos seculares", que a su vez provenía de la "Sagrada Congregación para los Religiosos" de Pío X en 1908, que remitía en fin a sus orígenes en 1586 con Sixto V como "Sagrada Congregación para las Consultas sobre los Religiosos".

La terminología más clásica habla de monacato ${ }^{6}$. Tal fue el punto de partida: cristianos inquietos y exigentes, arrastrados por la seducción de Dios (Jer 20,7), disconformes con una vida acomodada, sensibles a la llamada evangélica a dejarlo todo por el evangelio (Lc 18,29), abandonaban sus posesiones y proyectos, su familia pasada y futura, los placeres y bondades del mundo, y se recluían en lo más profundo de la civilización, donde no hubiera nada, donde solo pudiera intuirse el susurro de Dios, sin enojo-

${ }^{5}$ A. QUERALT, El valor de la consagración religiosa según el concilio Vaticano II: R. Latourelle (ed), Vaticano II. Balance y perspectivas. Veinticinco años después, Salamanca 1989, 817-843.

${ }^{6}$ Para lo que sigue, Monachisme: Dictionnaire de Spiritualité, X, Paris 1980, 1524-1617; Vie consacrée: Dictionnaire de Spiritualité, XVI, Paris 1994, 653-722; C.H. LAWrENCE, El monacato medieval. Formas de vida religiosa en Europa occidental durante la Edad Media, Madrid 1999. 
sas distracciones u ocupaciones. El horizonte era místico: el anhelo de Dios; y la marcha era ascética: evitar desvíos de recorrido. Se inspiraban en la llamada profética al ideal del desierto para el abandono total en Dios (Os 13,4s), en el desapego de Juan el Bautista (Mc 1,4ss), en el ejemplo del divino Maestro (Mt 4,1-11). Con razón se les calificó como monjes, de monakhós, 'solitario', dado su estilo de vida; como anacoretas, de anakhóresis, 'retiro', por su alejamiento radical; o eremitas, de éremos, 'desierto', por el lugar elegido de morada ${ }^{7}$.

Aparecieron más o menos simultáneamente, en los desiertos de Siria, Palestina, Mesopotamia y Egipto, y también espontáneamente, siguiendo la atracción del radicalismo evangélico y el ejemplo de ascetas extracristianos de la región (esenios, gnósticos, terapeutas...). La dureza de este estilo de vida hizo que debieran agruparse en colonias para apoyo mutuo, además de poder contar con la enseñanza de quien fuera su maestro espiritual. Así pasó con los discípulos de Antonio Abad en el desierto del bajo Egipto, en la segunda mitad del siglo III, un joven egipcio que heredó una gran fortuna de sus padres, pero herido por la llamada del evangelio lo dejó todo para instalarse en la nada, en el yermo de la sola escucha de Dios. Será considerado el padre del monaquismo por su celebridad e influjo tras la biografía sobre él escrita por san Atanasio, obispo de Alejandría.

El cenobitismo - de koinós-bíos, ‘vida común'- será la derivación más exitosa del monaquismo. Un legionario imperial de origen egipcio, Pacomio, impresionado por la caridad cristiana hacia los soldados, decidió convertirse y buscarse como aprendiz eremita. Pronto ideó, a principios del siglo IV, en la Tebaida egipcia, una experiencia monástica distinta: monjes habitando el mismo edificio, compartiendo oración y comida. Su saber militar le inspiró una "regla" detallista, igualitaria y flexible, en la que sería muy importante el orden común para la convivencia, el trabajo manual para la subsistencia y la obediencia al superior como intérprete unificador ${ }^{8}$. Era una solidaridad que posibilitaría la ascesis y la mística personales, asegurados conjuntamente cobijo, vestidura y alimento. El monacato cenobítico superaría en poco tiempo en popularidad al eremítico, fundando el mismo $\mathrm{Pa}$ comio monasterios masculinos y femeninos.

${ }^{7}$ Monakhós aparece ya en el Evangelio de Tomás 16; 49; 75. Monjes, monasterios, anacoretas y eremitas remiten a la Vida de Antonio de san Atanasio, traducida al latín rápidamente.

${ }^{8}$ La Regla de san Pacomio recoge la tradición de sus normas, y se conserva en la traducción latina de san Jerónimo, que denomina su estilo koinonía (Prefacio, 9). 
A finales de dicha centuria Basilio de Cesarea, tras peregrinar entre los eremitorios de las regiones pioneras, será el importador a Asia Menor del cenobitismo incipiente. Si Pacomio se había centrado en la organización práctica de la vida común, trascordando razones doctrinales, Basilio procederá al revés, dejando los detalles de lado y profundizando en la fundamentación bíblica y la justificación teológica. Describirá el cenobitismo como una suerte de soledad entre varios, entendiéndolo como el mejor modo de monaquismo, pues permite intensificar la dedicación a Dios mediante la ayuda mutua evitando las competiciones y extravagancias legendarias de estilitas, emparedados y pabulatores ('herbívoros'), y posibilitando la práctica de la caridad cristiana y la corrección del orgullo. Lo adaptará mediante emplazamientos más pequeños y urbanos, "fraternidades", dedicados a la oración y al trabajo manual e intelectual, pero también colaborando con el apostolado pastoral y caritativo ${ }^{9}$. Será el inspirador en Oriente de todo el monacato bizantino.

En Occidente la Regla más decantada y difundida será la de san Benito, a partir del siglo VI. Absorbiendo los modelos monásticos anteriores sintetizará Reglas previas orientales y occidentales, acomodándolas desde la moderación ascética y la sensatez humana -gobierno del abad mediante asambleas capitulares, dormir 7 horas y siesta en verano, 2 comidas diarias de dos platos (sin carne, salvo para los enfermos), 2 hábitos de abrigo- ${ }^{10}$. Su florecimiento en Italia y reconocimiento en Roma concederá a sus monjes el encargo papal de la misión en Britania, extendida a continuación a Centroeuropa, para ser después su Regla oficializada por el poder carolingio. Así preponderará sin discusión obviando todas las demás. Se basaba en una ordenación estricta del horario cotidiano, repartido entre el trabajo físico (sobre todo agrario) y el estudio y transcripción de manuscritos, la meditación individual mediante la lectura bíblica, y la cadencia periódica de la oración coral, un detalladísimo Oficio divino de las horas canónicas.

Con el II milenio se va a abrir paso un monacato de segunda generación -hoy diríamos monjes 2.0-. Asentándose en la tradición monástica anterior de entrega a Dios por la oración y la vida común, se integran en la revolución urbana, el surgimiento de burgos ricos por la agrupación de gremios artesanos que se desgajan del campo y de la sumisión feudal. Para in-

${ }^{9}$ La reglamentación de san Basilio proviene de colecciones de sus ideas ascético-monásticas recogidas en Pequeña Ascética (conservada en latín) y en su posterior ampliación Gran Ascética (subdividida como Reglas extensas y Reglas breves).

${ }^{10}$ Regla de san Benito 3; 8; 39; 55. 
sertar el evangelio en este ambiente promueven un estilo de pobreza e itinerancia predicadora, generando un monaquismo mixto de contemplación y apostolado. Nacen así franciscanos (1209) y dominicos (1216), seguidos tras su rápido crecimiento por otras muchas Órdenes. Al renunciar al trabajo para dedicarse preponderantemente a la predicación tendrán que vivir de los donativos de los fieles, serán llamados mendicantes. En muchos casos les servirá la Regla de san Agustín, genérica y abierta a la actividad pastoral, acogida algunos siglos antes por canónigos regulares y premonstratenses. Destacarán un espíritu interno más comunitario: habitan un conventus, 'reunión', más que un monasterium, 'solitariedad'; más fraterno: se denominan frailes, de fratres, 'hermanos', y sores, de sorores, 'hermanas'; más democrático: gobierno constitucional y capitular en vez de abacial, dirigido por un prior temporal, todo por votación; y más universal: su disponibilidad misionera es interterritorial, sin la estabilidad monástica benedictina. Las ramas femeninas quedarán más apegadas al modelo monacal anterior: no pueden atarearse en la predicación. En su sistematización teológica, Tomás de Aquino glosará este estilo como "vida religiosa" y "estado de perfección", elaborando una teorización de ello en torno a los consejos evangélicos ${ }^{11}$.

Con el advenimiento de la Modernidad y el humanismo, la defensa de lo humano como la referencia de todo, el monacato se revitalizará con el brote de la tercera generación: surgirán nuevas instituciones centradas en la acción caritativo-asistencial (hospitales, albergues, escuelas), extendida además a través de las misiones. No olvidan sus fundamentos monacales (oración, votos, vida común) ni el central servicio apostólico a la Iglesia de los mendicantes, cada progresión anterior se ha convertido en irrenunciable, pero los acompasan a un estilo más volcado en la promoción humana: el apostolado anterior doctrinal lo traducen en una acción prevalentemente social. Adquirirán entonces gran auge las congregaciones religiosas femeninas, que si no podían predicar sí encontraban campo abierto en esta labor asistencial, y particularmente la promoción femenina. De modo paralelo, tras la crítica disolvente de la Reforma al monacato, éste se revitalizará mediante la reforma continua de las Órdenes anteriores, en pos de mayor oración y exigencia ascética (descalzos, recoletos).

Dichas tres generaciones monacales comparten constantemente sus características generales, pero las combinan de modo diferente. Los monjes primeros eran fundamentalmente contemplativos, pero no negligieron

\footnotetext{
${ }^{11}$ Suma teológica II-II,81,1; 184,4s.
} 
la labor asistencial (albergues y hospitales monásticos), como tampoco la acción apostólica, asumiendo tareas pastorales donde no había parroquias e iniciando la predicación misionera (Britania, Centroeuropa, mundo eslavo). Los frailes tardomedievales destacaron el estilo predicador volcados en parroquias, misiones y universidades, pero sin querer olvidar la oración y vida comunes ni la solidaridad con los pobres mediante el acercamiento mendicante. E igualmente, las congregaciones de la modernidad se empeñarán más en las tareas asistenciales, pero integrando en ellas los anteriores aspectos de oración y kerigma. Esta clasificación ternaria aparece en el concilio someramente, como de pasada, mencionando su estilo "ya entregado a la contemplación en el monte, ya anunciando el reino de Dios a las multitudes, o curando a los enfermos y pacientes" (LG 46); pero también más expresamente, distinguiendo "los institutos que se ordenan íntegramente a la contemplación" (PC 7) y los dedicados a "la acción apostólica y benéfica" (PC 8). En todo caso, "el oficio principal de los monjes es rendir a la Divina Majestad un servicio a la vez humilde y noble dentro de los muros del monasterio, ora se consagren íntegramente, en vida retirada, al culto divino, ora emprendan legítimamente algunas obras de apostolado o de cristiana caridad" (PC 9).

La última recensión de la vida religiosa serían los institutos seculares -sus miembros son llamados consagrados seculares-, que a partir del siglo XX intentan la renovación monástica mediante un estilo que mezcle lo más posible lo religioso (los tres votos) con lo mundano (profesión civil), renunciando entonces a la vida común diaria (PC 11) $)^{12}$. Así que entonces la vida consagrada ya no sería sinónimo de la vida religiosa, pues los institutos seculares pertenecen a la primera sin ser de la segunda. Habría vida consagrada secular y vida consagrada religiosa. De modo parecido, no se integrarían en la vida consagrada las sociedades de vida apostólica, aunque sí se asemejan a ella, funcionando más o menos al revés que los institutos seculares: ejercicio del apostolado, tal vez mediante un trabajo secular, desde una "vida común sin votos" (PC 1), o votos sólo privados según reglamentación propia ${ }^{13}$. El carisma de ambas instituciones compondría una especie de secularidad consagrada, hasta ese momento poco menos que la cuadratura del círculo, realizando a su modo una de las grandes determi-

${ }^{12}$ Erigidos canónicamente con Pío XII en la Provida Mater Ecclesia, 1947. El Código de Derecho Canónico habla de ellos en los cánones 710-730.

${ }^{13}$ Ver Código de Derecho Canónico, 731-746 (particularmente nota introductoria de la edición de BAC, Madrid 1992). 
naciones del Vaticano II: el acudimiento de la Iglesia al mundo, la reconciliación entre cristianismo y sociedad moderna.

En conclusión, dum substantiam habeamus de nominibus non quaeramus. Si estamos de acuerdo en lo esencial de una manifestación particular de la vida cristiana, no perdamos mucho tiempo discutiendo la terminología.

\section{PRIMUM PROPTER QUOD IN UNUM ESTIS GONGREGATI}

¿Cuál es la esencia de la vida religiosa? ¿Dónde se ubica su finalidad? ¿En qué consiste su aportación a la Iglesia? Cabría componer aquí dos angulaciones a modo de respuesta, una más directamente individual, el origen último del carisma monástico, y otra más colectiva e institucional, conformando la significación eclesial.

\section{Llamada general}

Por más vueltas que se le dé, el monaquismo brota siempre de una vocación personal, se difumina en las profundidades y complejidades del individuo y la búsqueda de lo divino ${ }^{14}$. Es una atracción de Dios, una experiencia mística, una llamada de la trascendencia... O negativamente, como reverso de la moneda, una insatisfacción terrena, un deseo de liberación, un anhelo de plenitud... De Antonio el Eremita a Teresa de Calcuta, pasando por Francisco de Asís, todo comienza con una llamarada interior, una quemazón espiritual que la persona no puede apagar. Como dice san Agustín: "Primum propter quod in unum estis congregati, ut unanimes habitetis in domo et sit vobis anima una et cor unum in Deum"15.

Una de las grandes innovaciones del Vaticano II ha sido la democratización eclesial que ha inspirado. Es decir, no tanto que haya introducido estructuras jurídicas cuanto que ha insuflado aires democráticos: sínodo de obispos, conferencias episcopales, consejos diocesanos y parroquiales, para descentralizar la concentración del poder global en Roma y del local en las diócesis. La eclesiología también ha respirado esos aires: Iglesia como pueblo de Dios en vez de corporación institucional, revolución copernicana de

${ }^{14}$ Sobre esto F. WULF, Fenomenología teológica de las Órdenes religiosas: Mysterium Salutis, 4/2, Madrid 1975, 445ss. También LAWRENCE 17.

${ }^{15}$ Regla 3. 
la Lumen gentium ${ }^{16}$, eclesiología de comunión o participación en vez de jerárquica o autoritaria. E igualmente la pastoral ha ido por ese camino: vocación universal a la santidad, liturgia en lenguas vernáculas o comprensibles por todos, promoción del apostolado o testimonio laical... Pues bien, eso mismo ha alcanzado a la vida religiosa.

Para la LG la vida consagrada (cap. VI) se sitúa en el contexto de la vocación general a la santidad (cap V). "En la Iglesia todos, lo mismo quienes pertenecen a la Jerarquía que los apacentados por ella, están llamados a la santidad" (LG 39). Santidad alude al acercamiento a Dios y separación de lo profano. Dejando en suspenso lo segundo (a lo que luego volveremos), la llamada común a la santidad del concilio apuntaría a perseguir el ideal cristiano, que es el mismo para todos: ser perfectos como el Padre celestial es perfecto (Mt 5,48), encuadrar la existencia desde el amor a Dios y al prójimo (Mc 12,28ss), hacer de la propia vida un "culto espiritual" $(\mathrm{Rm} 12,1)$, una alabanza existencial agradable a Dios (1Pe 2,5). Tal llamada no es una extravagancia ajena al hombre ni una beatería trasnochada. Antes al contrario, corresponde al anhelo humano más profundo, presente en él desde siempre, denominado de muchas formas: Idea de Bien en Platón o búsqueda de Dios en Agustín, deseo de ver a Dios en Tomás de Aquino o nostalgia de trascendencia en Horkheimer... en suma, intuición de sentido. En ese anhelo, la santidad es dar un paso al frente. Así que "todos los fieles están llamados a la plenitud de la vida cristiana y a la perfección de la caridad" (LG 40).

Siendo esta llamada una voz de Dios audible en la fe, cada creyente la percibirá a su modo, pues el Espíritu de Dios sopla donde quiere (Jn 3,8) y el fiel no necesita que nadie le enseñe (1Jn 2,27). Los carismas, al tiempo dones de Dios y aptitudes humanas, son así inevitablemente multiformes: "cada cual tiene de Dios su gracia particular, unos de una manera y otros de otra" (1Cor 7,7). Los denominados "estados de vida cristiana" serán también formas diversas de responder a la común llamada de Dios a la santidad. La clasificación tradicional de dichos estados es la de clérigos, laicos y monjes. Desde comienzos de la patrística fue distinguiéndose entre clero y laicado, unos dirigiendo la comunidad cristiana y los otros conformando la colectividad creyente. A ellos se sumó el monacato, los ascetas retirados del mundo en eremos y monasterios, contrastando con los que permanecían en

${ }^{16}$ Los primeros esquemas consideraban en el capítulo 2: La Jerarquía, y en el 3: El pueblo de Dios. El documento final cambió su orden. Ver L. SuEnEns, Recuerdos y esperanzas, Valencia 2000,144s. 
él o saeculares ('seglares'). Esta segunda clasificación aglutinaba la anterior, y asumiendo los monjes el clero y el laicado quedaba la duda de si eran algo aparte o integrado: duo sunt genera christianorum, glosará Graciano un dicho atribuido a san Jerónimo; tres emissiones in Ecclesia, prefiere decir san Bernardo ${ }^{17}$. Pío XII siguió la segunda idea al poner a los religiosos como estado intermedio entre los otros $\operatorname{dos}^{18}$, pero el concilio prefirió la primera opinión: "este estado no es intermedio entre el de los clérigos y los laicos, sino que de uno y otro son llamados algunos cristianos" (LG 43). El nuevo Código de Derecho Canónico recambia una vez más la opción, aunque solo teóricamente, tratando con buena lógica primero de los fieles, luego de la jerarquía y finalmente de la vida consagrada (libro II, partes I-III). Jurídicamente los religiosos son sacerdotes o laicos, pero teológicamente componen un tercer estilo de vida.

En todo caso, independientemente de si son dos o tres las formas de vida cristiana, lo lamentable ha sido la subyugación de una clase frente a las otras. Los cristianos somos todos hermanos, pero parecemos haber segregado a algunos primos. El laicado ha sido el patito feo de la estructura eclesial: los que obedecen y están sometidos a la jerarquía (nada menos que desde la I Carta de Clemente, a principios del siglo II), los ignorantes y legos (evolución de la palabra 'laico') frente al culto clero, los enfangados en el mundo o seglares (de saeculares, 'mundanos') ante los elevados religiosos, los sustentadores económicos (por tanto 'paganos') del ministerio, dedicado a la Iglesia y sin ganancias temporales ${ }^{19}$. Una de las revoluciones del Vaticano II será precisamente superar esta inferiorización, pensar la Iglesia primero como pueblo de Dios, consideración previa a su diversificación en ministerios y funciones (LG, cap II). El laicado es el fundamento, la base de la vida eclesial, la condición general del ser cristiano, de donde surgen ministros y monjes. Su carácter mayoritario, su irradiación universal, les hace imprescindibles en una evangelización que quiera alcanzar todos los rincones. Compensando las otrora despectivas miradas al mundo y el laicado, bellamente expone el concilio que "en todas sus obras, oraciones y apostolado, vida conyugal y familiar, el cotidiano trabajo, el descanso del alma y del cuerpo, (...) los laicos consagran el mundo mismo a Dios" (LG 34). Consagrar el mundo a Dios, esto es, vivir la vida desde los valores evangélicos, la confianza en Dios y el amor al prójimo, construir cristianamente la sociedad.

\footnotetext{
${ }^{17}$ Graciano, Decreto II,12,1,7; Bernardo de Claraval, Sermones 91,1.

${ }^{18}$ Provida Mater Ecclesia, 1947, 4.

${ }^{19}$ Sobre esto, T. MARCOS, Laicos e Iglesia: Estudio Agustiniano 27, 1992, 530-533.
} 
Por su parte, el carisma del sacerdocio cristiano consistiría en el "don de gobierno" (1Cor 12,28), "de ministerio" o "de presidencia" (Rm 12,7s). Su esencia estaría en la paradoja que encierra: un carisma institucional. En cuanto don divino supone unas aptitudes personales, pero siendo también un ministerio ('servicio') de gobierno implica una elección oficial. Su encargo es la tarea de dirección eclesial, ser jerarquía ('poder sagrado'), pero entendida de un modo análogo, pues la Iglesia es comunidad de fe y no tanto sociedad humana. Es decir, los creyentes reconocen al sacerdocio una autoridad sacramental (concedida por Dios), pero solo en cuanto puesta al servicio de la comunión (participación común en la fe), desglosada como trasmisión doctrinal, presidencia comunitaria y administración sacramen$\mathrm{tal}^{20}$. En palabras del concilio: "han sido consagrados como sacerdotes (...) para predicar el evangelio, apacentar a los fieles y celebrar el culto divino" (LG 28), "ministros que en la Iglesia poseen la autoridad sagrada" (PO 2).

Y por fin, el carisma propio de la vida religiosa sería la "total consagración de sí mismo a Dios" (LG 44). Esta fórmula no conlleva ningún juicio de valor, pues los carismas no son mejores ni peores -exceptuando los de la caridad y la construcción comunitaria, abiertos a todos (1Cor12,4ss)-, sino regalos de Dios y cualidades personales. Son valores subjetivos (y aportaciones comunitarias) y cada uno tiene el suyo. Dicha entrega a Dios quiere ser completa y personal, y por ello el monje se retira del mundo, se recluye en el claustro, huyendo de digresiones, para enfocar su mirada en la llama divina que arde en su interior sin consumirse. No es que el mundo sea malo, sino que le absorbe la fascinación de Dios. El aprecio de la tierra, la valoración de las realidades temporales (GS 36), es otra de las innovaciones del concilio para su correcto ajuste a los tiempos modernos. Además, como la fe cristiana aúna el amor a Dios y al prójimo (1Jn 4,20), el monacato siempre ha asumido la acción pastoral y caritativa, la consagración total de sí a Dios no puede excluir la entrega al prójimo y la Iglesia.

\section{Significación institucional}

Khárisma es 'don', el efecto que la benevolencia divina instala en todo cristiano, "distribuyéndolo a cada uno en particular" (1Cor 12,11). Pero dicha aptitud individual solo puede ser llamada carisma en cuanto sirve a

${ }^{20}$ Más sobre el particular en T. MARCos, Identidad móvil. La insoluble ambigüedad del sacerdocio cristiano: Estudio Agustiniano 45, 2010, 396-399. 
construcción de la comunidad, "a cada cual se le otorga la manifestación del Espíritu para provecho común” (1Cor 12,7). Pues bien, la vida religiosa es "un don divino que la Iglesia recibió de su Señor" (LG 43). Entonces, el carisma monástico ${ }^{21}$, en cuanto institución, ¿qué añade a la edificación de la fe? ¿Cuál es su finalidad, su razón de ser en la Iglesia y para el mundo?

Yves Congar señaló que "la vida religiosa no pertenece a la esencia de la Iglesia..." Superada nuestra estupefacción, y antes de llamar traidor al ilustre dominico, conviene seguir leyendo: “(...) en su estructura jerárquica", pero sí en lo que concierne a su interioridad, "en el acto de responder a la llamada del Señor" 22 . Además, lo dice también el concilio: la vida religiosa "no entra en la estructura jerárquica de la Iglesia" (LG 44). Sabido es que la Iglesia configura un misterio de fe: el aleteo del Espíritu en una comunidad humana, Dios presente en avatares organizativos sociales. Pues bien, la vida religiosa se enmarca en el flujo carismático de la articulación eclesial, estructurándose ella misma, sí, pero evitando que su estructura conforme ninguna jerarquía en la Iglesia. La vida consagrada no tiene pretensiones de mando en la Iglesia, es solo un signo.

En realidad, como ya ha sido dicho, todos los estados de vida cristiana participan de la común vocación a la santidad, e igualmente cada uno de ellos contribuye a su modo a la edificación de la Iglesia. El laicado, mediante la consagración del mundo, declarando que la vida terrena es susceptible en todos sus resquicios de los valores cristianos. El sacerdocio, a través del servicio a la comunidad eclesial, velando por la cohesión y vitalidad de la comunión de fe. Y el monacato, desde la consagración total a Dios, señalando la temporalidad de las cosas terrenas, "el seguimiento de Cristo tal como se propone en el evangelio" (PC 2), recordando la referencia última del ser cristiano.

La vida religiosa es "como un símbolo que puede y debe atraer a todos los miembros de la Iglesia a cumplir los deberes de la vida cristiana” (LG 44). El pueblo de Dios no encuentra en la tierra ciudadanía permanente, se sabe tendido a la futura. Como oí comentar a una señora en el pueblo, anonadada ante la muerte repentina por infarto de un vecino: 'no somos de

${ }^{21}$ Pablo VI utiliza por vez primera el término 'carisma' referido tanto a la particularidad de la vida consagrada como a la de cada instituto religioso (Evangelica testificatio, 1971, 11;32). Ver J. BEYER, La vida consagrada por los consejos evangélicos: doctrina conciliar y desarrollos posteriores: Latourelle 856.

${ }^{22}$ Advertencia: VV AA, La adaptación y la renovación de la vida religiosa. Vaticano II, Madrid 1969, 12. También G. PHILIPS, La Iglesia y su misterio en el concilio Vaticano II. Historia, texto y comentario de la constitución Lumen gentium, II, Barcelona 1969, 158.181. 
aquí, estamos de prestado'. Es lo que desliza teológicamente la revelación: "sois conciudadanos de los santos y familiares de Dios" (Ef 2,19). Los institutos religiosos, en cuanto promueven la relativización de las preocupaciones mundanas, por un lado manifiestan a todos "que los bienes celestes se hallan ya presentes en este mundo", que es posible pregustar en vida la unión con Dios; y al revés, "testimonian la vida nueva y eterna" aquí en la tierra, son signo escatológico al "prefigurar la gloria del reino celeste" (LG 44). La vida religiosa es además signo cristológico. Para los monjes, como para todo cristiano, la búsqueda de Dios se realiza a través de Cristo. La sequela Christi es "norma última de la vida religiosa" (PC 2), indicación para los creyentes de que la fe cristiana es sobre todo memoria Iesu.

La vida religiosa es así signo de la caducidad de lo mundano y de la eternidad del evangelio, expresión de que lo más valioso de la existencia humana sobrepasa la temporalidad, apunta a lo absoluto y trascendente. Es un grito contra las pretensiones de plenitud del mundo, expresa con su estilo de vida de dedicación a Dios y renuncia a bienes terrenos, que la perfección no está aquí. Una vez más, no se trata de la fuga y el desprecio del mundo, atrás quedan los tres enemigos del alma (mundo, demonio, carne) de la espiritualidad tradicional. El mundo es lo único que tenemos, es nuestra casa, la queremos bella y habitable. Pero no es el todo ni lo último. En realidad es solo un instante, "una sombra que pasa" (Sal 144,4), verdaderamente "lo penúltimo" 23, una transición hacia Dios. Tal significación es la que quiere ejemplificar el carisma monástico. "La esencia y voz del monacato como renuncia a las satisfacciones mundanas conserva su vigencia intemporal en la Iglesia, es la morada viva de la fe en un mundo pasajero. (...) La existencia cristiana, con su orientación escatológica, queda patente en el testimonio que de ella ofrece el monacato"24.

El concilio se muestra orgulloso de la inserción de la vida religiosa en la existencia cotidiana. "La profesión de los consejos evangélicos, aunque implica la renuncia de bienes que indudablemente han de ser estimados en mucho, no es sin embargo un impedimento para el desarrollo de la persona humana". Además "los religiosos, por su consagración, no se hacen extraños a los hombres o inútiles para la sociedad terrena, pues si en algunos casos no sirven directamente a sus contemporáneos, los tienen sin embargo presentes de la manera más íntima en las entrañas de Cristo y cooperan espiritualmente con ellos, (...)

${ }^{23}$ D. BonhoefFer, Ética, Barcelona 1968.

${ }^{24}$ U. Ranke-Heinemann, Monacato: H. Fries (ed), Conceptos Fundamentales de la Teología, 3, Madrid 1967, 128. 
y en los monasterios o en las escuelas y hospitales o en las misiones (...) prestan a todos los hombres los más generosos y variados servicios" (LG 46).

\section{HAEC SUNT QUAE PRAECIPIMUS IN MONASTERIO CONSTITUTI}

Dedicación primordial a Dios, parábola del reino futuro, seguimiento radical de Cristo, tal es el carisma y tarea de la vida religiosa. Ahora bien, ¿cómo llevar la teoría a la práctica? ¿Cómo convertir en vividos o vívidos dichos ideales? Desde los primeros momentos de la existencia monástica se fueron institucionalizando tres mecanismos axiales que la caracterizan a partir de entonces.

\section{Oración}

La vocación religiosa llama a "vivir únicamente para Dios, entregar la vida entera al servicio de Dios", de modo que "dejándolo todo por Cristo (Mc 10,28) le sigan a él (Mt 19,21) como a lo único necesario (Lc 10,42), oyendo sus palabras $(\mathrm{Lc} 10,39)$ y dedicándose con solicitud a los intereses de Cristo (1Cor 7,32)" (PC 5). Esta entrega total a Dios solo puede materializarse mediante la oración. "Por eso, los miembros de los institutos deben cultivar con asiduo empeño el espíritu de oración y la oración misma" (PC 6). El "espíritu de oración", la intención de la oración, aludiría a la contemplación, la percepción espontánea y continua del misterio trascendente en las cosas y los días, la meta última de los monjes, "por la que se unen a Dios en mente y corazón" (PC 5). "La oración misma", la concreción de la oración, se va a condensar tanto de modo individual como colectivo: lo primero como lectio divina, lo segundo mediante el oficio divino.

Lectio divina es 'lectura sagrada', referida por supuesto a la palabra de Dios, la lectura meditada de la Biblia. Se lee una novela por diversión, un libro científico para información, y la Escritura para escuchar la palabra de Dios. Recomendada así por los Padres a todos los cristianos, los monjes la incorporarán a su actividad central, textos y frases y palabras que los pioneros del desierto leerán o memorizarán y se repetirán para tenerlos continuamente presentes, en una meditatio o ruminatio incesante, para así poder vivirla y trasmitirla a quien les pida consejo ${ }^{25}$. "Orad sin cesar" dice la Escritura (Lc 18,1;

${ }^{25}$ San Atanasio, Vida de Antonio 3,6s; 25,1; 55,2s; Regla de san Pacomio 1,19. 
1Ts 5,17). El quehacer monástico, aparte del trabajo, será una alternancia continua que va de la oración a la lectura y de la lectura a la oración, tanto de noche como de día. Por tanto, 'rezar, rezar, rezar y volver a rezar', que diría el sabio (de Hortaleza). Escritura y meditación son los ingredientes de la lectio divina, la lectura bíblica como armazón que sujeta el mortero fluido del pensamiento, componiendo juntos una sólida construcción. Esta recitación y reflexión continua de la Biblia les llevará a una comprensión que se renueva continuamente, la autonomía del texto y el círculo hermenéutico de que habla la filosofía moderna, las múltiples sugerencias que evoca cada lectura según las diversas circunstancias y épocas del lector. Leer la Biblia aplicándose sus enseñanzas, sintiéndolas en el corazón, dejándose transformar por ellas... La lectio divina será una fuente incesante de la sabiduría de los monjes.

En el II milenio la lectio divina va a ir cambiando de comprensión. En vez de eje de la rutina monástica será un método de lectura de la Escritura, que además amplía su campo de acción a los Padres de la Iglesia. Será propuesto en oposición a la incipiente teología escolástica, que desarrollaba su estilo académico como un proceso que partiendo de la lectio o estudio racional del texto, continuaba con la quaestio o formulación de los interrogantes suscitados, para acabar como disputatio, la dialéctica en busca de solución. La teología monástica, por el contrario, comenzaría con la lectio, lectura desde el corazón más que con la cabeza, proseguida luego con la meditatio o interiorización personal y la oratio o respuesta espontánea, para así culminar en la contemplatio, la persuasión habitual de la presencia de $\operatorname{Dios}^{26}$.

Hoy día, en el último estadio de esta evolución, se ha diluido seguramente el espíritu originario de la lectio divina. Los religiosos se dedican más a ser competentes en los apostolados y tareas institucionales, han ido olvidando el ideal primigenio de oración continua en búsqueda constante de Dios, condensado en la lectura reposada y reflexiva y reiterada de la $\mathrm{Bi}$ blia, de modo que impregne el discurrir completo de la vida y las horas. Pero más que una obligación, la oración es una suerte: sus virtudes de abarcar el pasado, presente y futuro desde lo trascendente y supraindividual; de reposar, repasar y sopesar nuestro tiempo y acción tienen una eficacia humana: de identidad, evaluación y proyección; y por supuesto espiritual: de autoconvencimiento y compromiso. En cualquier caso sigue vigente el horizonte antiguo: "tengan ante todo diariamente en las manos la Sagrada Escritura, a fin de adquirir por la lectura y meditación de los Sagrados Libros el sublime conocimiento de Jesucristo" (PC 6).

${ }^{26}$ C. De Dreuille, Lectio divina. Un camino para orar la palabra de Dios, Estella 2014. 
La oración colectiva se fijará en el officium divinum de las horas. La oración personal como cadencia del decurso diario está atestiguada ya en Israel, primero al comienzo y final del día (Dt 6,7;11,19), y luego extendida a media jornada (Dn 6,11.14). Siguiendo y actualizando esa tradición, Tertuliano enmarca los tiempos de oración en cinco: las tres horas romanas de tertia, sexta y nona, además de al comenzar y terminar el día, mientras Hipólito de Roma añade dos nocturnas, llegándose así al número siete, siguiendo el mandato bíblico (Sal 119,164) y la sugestión simbólica de dicho número ${ }^{27}$. San Pacomio pondrá como obligatoria la recitación y meditación sálmica común, al comenzar y terminar el día, de modo que para el cenobitismo la oración colectiva como un deber compondrá un entramado central, de ahí el officium ('tarea') divino ${ }^{28}$. También Basilio va a insistir en la oración común, pero más frecuente, pautando las horas de oración en ocho: en torno al amanecer, el día según la división romana (tercia, sexta, nona), el atardecer, el anochecer, la medianoche y antes del alba ${ }^{29}$. Si el rezo catedralicio, con el obispo y presbiterio, se ciñe al comenzar y terminar el día, intercalando rituales de luz e incienso en la declamación de los salmos, el ideal monástico de oración ininterrumpida fijará abundantes tiempos, suprimiendo ceremoniales, centrados sólo en la recitación, meditación y canto. Tenderán entonces a fijarse esas horas en siete diurnas y una nocturna ("por la noche me acuerdo de ti", Sal 119,62). San Benito universalizará dicho esquema en el Occidente europeo, el Opus Dei de las horas canónicas: 1 nocturna o vigilias (maitines) más 7 diurnas (laudes, prima, tercia, sexta, nona, vísperas y completas), siguiendo un orden temático de modo que cada semana se completen los 150 salmos $^{30}$. La plegaria pautada común redunda en bien de la individual: constriñe externamente a ella y crea una atmósfera orante. Y la oración personal madura y eleva el rezo colectivo. El círculo virtuoso de la oración.

El II milenio conocerá la transición de la liturgia coral de las horas a la recitación privada del breviario. Al comenzar la ordenación sacerdotal sin ligazón a una iglesia, el oficio divino pasó a ejercerse de modo individual, y un libro recopiló (breviarium, 'resumen') todo el rezo diurno abreviando lecturas y oraciones. Los monjes que realizaban cura de almas en parroquias sin presbítero podían compensar la ausencia de oración de coro con el breviario, y las nuevas Órdenes mendicantes, que vivían volcadas en la ac-

\footnotetext{
${ }^{27}$ Tertuliano, La oración 24s; Hipólito, Tradición Apostólica 41.

${ }^{28}$ Regla de san Pacomio 1,19.23; 2,14.

${ }^{29}$ Reglas extensas 37,3-5.

${ }^{30}$ Regla de san Benito 16-18.
} 
ción pastoral y sin stabilitas loci, también se acomodaron a la recitación privada fuera del monasterio. Esta época conoció también el officium parvum, una síntesis adicional sálmica en honor de la Trinidad, la Virgen o un santo, que separada del oficio mayor sirvió de oración a laicos instruidos.

El Vaticano II concluirá esta evolución menguando, desde las circunstancias actuales, la obligación estricta del oficio divino a laudes y vísperas, flexibilizando maitines para poderse rezar también en horas diurnas, actualizando Completas y eliminando prima (SC 89). La ha denominado "liturgia de las horas" y considerado como una posibilidad de oración universal, volviendo a sus orígenes, por tanto abierta a todos los cristianos (y así de uso en general privado). Pero no parece que haya calado dicha pretensión, y sí por el contrario haberse diluido la misma oración de las horas. Habría que pensar que el aprovechamiento máximo del oficio divino está muy ligado a la recitación coral; y al revés, que la oración comunitaria cotidiana tiene en la liturgia de las horas un inmejorable asidero. Desgraciadamente, aparte de las Órdenes primordialmente contemplativas, que mantienen la obligación de oración coral, el resto de religiosos se perciben demasiado absorbidos por exigencias del apostolado educativo, social, pastoral y misionero. Cabría rementar aquí la consigna de santo Tomás: la contemplación ha de preceder a la acción ${ }^{31}$.

\section{Votos}

Popularmente hablando, lo primero que caracteriza la vida religiosa son los votos monásticos. El concilio también parece haberlo entendido así, sellando varias veces el mantra de la "vida consagrada a Dios por la profesión de los consejos evangélicos" (PC 1; 6; LG 44;46). Efectivamente es una de las particularidades centrales del monaquismo. El ascetismo ansiado por los monjes pioneros les llevó a desprenderse de todo, aunque no lo llamaran pobreza, era más bien la convicción de no precisar absolutamente nada para la dedicación a lo único necesario, Dios. La desposesión plena, el desprecio de todos los aprecios materiales, estuvo muy presente en el surgimiento de la vida ascética ${ }^{32}$. Por otra parte, querían abandonar completamente el mundo y sus afanes, dejar amigos y familia pasada, renunciando a la futura, concentrarse exclusivamente en la contemplación, de modo que la castidad fue con-

\footnotetext{
${ }^{31}$ Tomás de Aquino, Suma teológica II-II,182,4.

${ }^{32}$ San Atanasio, Vida de Antonio 2,2ss.
} 
natural al intenso impulso de devenir monakhós, solitario en Dios. Y finalmente, al encumbrarse el estilo cenobítico por encima de las otras modalidades monacales, conllevó para su buen funcionamiento una disciplina obediente en torno a una Regla y un $\mathrm{abad}^{33}$, renunciar a la propia voluntad para entregarse a la llamada y voluntad de Dios.

El votum, la 'promesa' hecha a los dioses, compone una práctica universal del espíritu religioso, sea propuesto como 'obligación' tras la concesión de una gracia (ofrecer sacrificios, iniciar una peregrinación, aportar para un templo), sea intuido como 'deseo' que se impetra a la magnanimidad divina (salud, éxito, cargo) ${ }^{34}$. En el mundo antiguo, dominado por lo sobrenatural y la inseguridad de la existencia, era una característica común de la vida (Gn 28,20; Nm 21,2). Estaba unido a la oración de petición y conllevaba un aspecto de ofrenda, estableciendo lazos con la divinidad. La entrega de sí tiene un precedente en el nazireato de Israel, de la raíz $n z r$, 'separado', una consagración temporal personal y distintiva, por la que uno se ofrece a Dios mediante obligaciones vitales: no beber vino, no cortarse el cabello, no acercarse a un cadáver (Nm 6,1ss). La consagración religiosa por los votos monásticos significaría pues la dedicación radical a lo divino mediante la separación de lo mundano.

Inicialmente no hubo votos explícitos, una declaración formal de compromiso de pobreza, castidad y obediencia, puesto que quedaban implícitos en la decisión monacal de retirarse del mundo y habitar en un monasterio. Sería la Regla de san Benito la que introduciría la formulación de votos, en este caso de estabilidad, conversión y obediencia ${ }^{35}$, que luego con los primeros mendicantes, en el siglo XIII, adquiriría la actual nomenclatura $^{36}$. El orden conciliar de los votos fluctúa ente el más común de castidad, pobreza y obediencia (LG 43; PC 1;12-14; 25), y el menos frecuente de castidad, obediencia y pobreza (LG 42). Sin embargo, el orden histórico mendicante sería el más clásico: pobreza, castidad y obediencia, generalizado después a través de la espiritualidad religiosa. El listado patrístico es variable, prevaleciendo el seguido por el concilio ${ }^{37}$. Y ya puestos, el orden

${ }^{33}$ San Benito sentencia que "cenobitas son los que viven en un monasterio bajo una Regla y un abad" (Regla 1,2).

${ }^{34}$ A. Queralt, Voeu: Dictionnaire de Spiritualité, XVI, Paris 1994,1167-1195.

${ }^{35}$ Regla de san Benito 58,17.

${ }^{36}$ SAn Francisco, II Regla $1,1$.

${ }^{37}$ La Regla de san Agustín enmarca la castidad (cap. 4) entre la austeridad (cap. 3) y los bienes comunes (cap. 5), ambos por tanto referidos a la pobreza, y seguidos luego por la obediencia (cap. 7). 
evangélico tal vez sería el de obediencia, castidad y pobreza (Mc 8,34; $10,29)$. No parece que tenga demasiada importancia, como aprendimos en la escuela el orden de factores no altera el producto.

Aunque el concilio parece considerar en general como expresiones sinónimas votos monásticos y consejos evangélicos (PC 1), no debiera en absoluto entenderse así, pues "la santidad de la Iglesia se fomenta con los múltiples consejos que el Señor propone en el evangelio para que los observen sus discípulos" (LG 42). Toda la enseñanza evangélica viene a ser un compendio de exigentes consejos religiosos: no resistir el mal con el mal, perdonar siempre, buscar la paz... que superan la estructuración monacal en los tres votos de pobreza, castidad y obediencia. La terminología apareció al distinguir los Padres, siguiendo a san Pablo (1Cor 7,25), entre mandamientos y consejos, los primeros de obligado cumplimiento para todos, y los segundos como exhortaciones para los que buscan la perfección ${ }^{38}$. Naturalmente, los votos se encuentran también entre los consejos evangélicos, y así lo percibieron los promotores del monaquismo, la pobreza en la historia del joven rico y en las invectivas de Jesús contra la riqueza, o en su llamada a dejarlo todo (Mc 10,17-30); la castidad en esa misma llamada y en la alabanza de los eunucos por el reino (Mt 19,12), así como en las amonestaciones de Pablo al celibato para no tener el corazón dividido (1Cor 7,32ss); y la obediencia en las condiciones del seguimiento de Jesús como negación de uno mismo (Mc 8,34), o en su ejemplo de anonadamiento y sumisión (Fil 2,7s).

Los votos se entendieron desde el primer momento como los medios más adecuados para propiciar el fin del monacato: la dedicación plena al misterio divino y el seguimiento radical de Jesucristo. Eran rechazos de todo lo que distorsionara la concentración en Dios: las posesiones, los placeres, la autoafirmación. En aquel entonces se concibieron como males que desviaban el corazón de su camino auténtico, incluso como perversiones del alma. En todo ello latía la mentalidad órfica, la concepción dualista oriental integrada en la cultura helenista, que exaltó el espíritu como la veracidad humana y denigró el cuerpo como su cárcel, difundida a través del platonismo y gnosticismo, y luego propagada mucho más por el cristianismo ${ }^{39}$, precisamente por la ejemplaridad monástica además del neoplatonismo del pensamiento patrístico.

Hoy día no podemos entenderlo así, sería justamente una de las acomodaciones a los tiempos que nos pide el concilio. Los votos siguen siendo

\footnotetext{
${ }^{38}$ PHILIPS II,139-153.

${ }^{39}$ E. DodDs, Los griegos y lo irracional, Madrid 1983, 133-169.
} 
renuncias necesarias para encaminarse al ideal monástico de la entrega completa a Dios. Pero son renuncias a cosas positivas -haberes, familia, libertad-, a bienes apreciados del mundo, en sí mismo también apreciado (GS 36). La psicología moderna habla de la autorrealización como meta sublime de la existencia, poder ser uno mismo, coincidente con el ideal clásico de la vida buena ${ }^{40}$. La propia vida es lo único que tenemos mientras no se demuestre lo contrario, y la fe es indemostrable, aunque es lo único que da sentido a la vida más allá de sí misma, pues en sí ni tiene ni deja de tener sentido. Los bienes y placeres del mundo, si no se absolutizan como una buena vida, son valiosos para una vida buena. Pero muchas veces suelen tiranizar la existencia, actúan como tentaciones irresistibles de riqueza, dominio y fama, síntesis de las pruebas de Jesús en el desierto (Lc 4,1ss), o se convierten en instintos devastadores de placer y poder, origen freudiano de todas las neurosis habidas y por haber. Por si esto sonara a galimatías, digámoslo más simplemente: "la profesión de los consejos evangélicos, aunque implica la renuncia de bienes que indudablemente han de ser estimados en mucho, no es sin embargo un impedimento para el verdadero desarrollo de la persona humana" (LG 46).

La castidad "libera el corazón (...) para encenderse en el amor de Dios y de todos los hombres", para la oración, el apostolado y la caridad; siendo también "signo especial de los bienes celestes" y de la vana consistencia de lo terreno; así que no va a "dejarse conmover por las falsas doctrinas que presentan la castidad perfecta como imposible o dañosa para la plenitud humana" (PC 12), sino todo lo contrario. Por su parte, "la pobreza voluntaria por el seguimiento de Cristo es un signo hoy particularmente muy estimado" (PC 13). Será porque vemos y sentimos que la absolutización de la riqueza es un mal absoluto, como el pecado contra el Espíritu Santo (Mc $3,29)$, que reduce los verdaderos valores -la amistad, la salud, el disfrute, el descanso...- a naderías ridículas. Sin embargo, no sabemos quitárnosla de encima, aunque "no se puede servir a Dios y al dinero" (Lc 16,13). Finalmente, la obediencia es "el sacrificio de sí mismo, la plena entrega de la voluntad para unirse más constante y plenamente a la voluntad salvífica de Dios". No es ninguna aniquilación masoquista, sino la reorientación del propio valer mediante "la sumisión a los superiores (...) para el servicio a todos los hermanos (...) y el servicio de la Iglesia”, la realización de sí mismo mediante la disponibilidad hacia los demás, de modo que "la obe-

${ }^{40}$ Aristóteles, Ética a Nicómaco 1095a; D. Nettle, Felicidad. La ciencia tras la sonrisa, Barcelona 2006. 
diencia religiosa, lejos de menoscabar la dignidad de la persona, la lleva, por la más amplia libertad de los hijos de Dios, a la madurez" (PC 14).

\section{Vida común}

La comunidad es la tercera pata de la institución monástica. Haciendo un símil militar, si el objetivo o meta final del monacato es la unión con Dios (la mística), y la estrategia o plan teórico son los votos de renuncias (la ascética), la táctica o método práctico será la vida en común (la comunión). El ideal antiguo del abandono completo en Dios mediante la desposesión absoluta del anacoretismo se percibió inmediatamente como heroico, al filo de lo imposible. De manera que al poco tiempo brotó el cenobitismo, un sistema que mantenía el ideal místico, pero afrontado mediante el apoyo mutuo entre los eremitas, y que en una especie de evolucionismo espiritual fue el que prevaleció, deviniendo la mejor adaptación a una necesidad (el radicalismo religioso) de los órganos disponibles (las capacidades humanas) para su supervivencia o continuidad en el tiempo. El eremitismo, en cambio, aunque haya podido proseguir, ha languidecido históricamente entre la excentricidad y la insignificancia.

Incluso en los comienzos de san Antonio Abad se crearon en torno a él una especie de vecindarios eremíticos, en los que los ascetas mantenían un estricto compromiso de oración en soledad, pero se aproximaban entre sí para aprender las enseñanzas del maestro, y también brindarse apoyos esporádicos en su empeño ${ }^{41}$. Un exigente ideal como la entrega máxima a la experiencia de Dios, en continua oración y meditación, que descuida por tanto las necesidades físicas básicas, requeriría primero asegurar la subsistencia, lo que se conseguirá más fácilmente aunando y coordinando esfuerzos para un cobijo sólido y provisiones a largo plazo. Liberar de preocupaciones materiales sería la idea pacomiana que, como militar y eremita, le condujo a la camaradería anacorética organizada. Intenta igualmente sostener la exigencia anímica, remontar los altibajos, desfallecimientos y noches oscuras del aislamiento prolongado, lo que solo puede remediarse con la oración y convivencia (capilla y mesa) de la soledad compartida ${ }^{42}$.

El estilo cenobítico enlazaba bien con las idealizaciones de la comunidad primitiva de Jerusalén: "los creyentes vivían unidos y tenían todo en común, vendían sus posesiones y sus bienes y repartían el precio entre

${ }^{41}$ San Atanasio, Vida de Antonio 4,1ss.

${ }^{42}$ SAn Basilio, Reglas extensas 7,1ss. 
todos, según la necesidad de cada uno (...) Tenían un solo corazón y una sola alma, y nadie llamaba suyos a sus bienes sino que todo era común entre ellos" (Hch 2,44s; 4,32). Estas idílicas perspectivas fomentaban la ensoñación monástica, la realización vanguardista de la utopía cristiana. La utopía es un horizonte nunca alcanzable (ou-tópos, 'sin-lugar'), pero mantenerlo delante permite avanzar aunque solo sea un poco hacia él. Es algo así como la lotería: nunca toca a casi ninguno de los que la juegan, pero evidentemente menos tocará a los que no la juegan. "Ante todo, habitad unánimes en la casa, con una sola alma y un solo corazón en camino hacia Dios", espeta para empezar la Regla de san Agustín, añadiendo a continuación: “y no consideréis nada como propio, sino tenedlo todo en común"43.

La vida comunitaria se percibió igualmente como un magnífico instrumento para el cumplimiento efectivo de la oración y los votos. El ritmo frecuente de la liturgia de las horas creaba una atmósfera envolvente de oración, flotando también en las pausas, impulsando a la contemplación, a la perenne presencia de Dios. Asimismo, "proteged recíprocamente vuestra pureza", comenta san Agustín, "pues Dios, que habita en vosotros, os protegerá también de este modo desde vosotros" 44 ; lo ratifica el concilio: "la castidad se guarda más seguramente cuando entre los hermanos reina verdadera caridad fraterna en la vida común" (PC 12). La necesidad afectiva que toda persona precisa y construye en la familia, y a la que el monje renuncia por el voto de castidad, sería de algún modo compensada por la convivencia y amistad comunitaria. El voto de pobreza, por su parte, quedará muy eficazmente canalizado por "la ley común del trabajo" (PC 13), mediante la que se fortalece la estructura comunitaria a medida que se rehúsa la ganancia personal. El trabajo desinteresado en pro del bien común es uno de los secretos no guardados de la potencia material monástica, aunque también fuente de problemas y divisiones con los continuos movimientos internos de reforma ${ }^{45}$. Finalmente, una estrecha vida en común exige el voto de obediencia al superior y a las reglas colectivas para su buen funcionamiento. De hecho, la obediencia ha sido connatural al nacimiento del cenobitismo, forma parte intrínseca del desenvolvimiento ordenado de la vida común.

${ }^{43}$ San Agustín, Regla 3. Tal es el comienzo según la edición crítica de L. VerHEIJEN, La règle de saint Augustin, París 1967, al que la tradición habría antecedido unas frases de redondeo.

${ }^{44}$ Regla 24.

${ }^{45}$ Cluniacenses renovando a los benedictinos, cistercienses a los cluniacenses, trapenses a los cistercienses... conventuales refundando a los franciscanos, capuchinos a los conventuales, terciarios a los capuchinos... 
Para que la vida común funcionara correctamente era necesaria una estricta paridad interna. 'Del abad abajo, ninguno', podría ser el primer lema, parafraseando el teatro hispánico; prior inter pares, adecuarían el adagio clásico los frailes. Una estrecha convivencia entre muchos, bajo el mismo techo, con idéntico horario, con posesiones comunes, con el mismo alimento... o se fundamenta en una fraternidad igualitaria o no puede funcionar, celos y rencillas sobre quién trabaja más y come menos malbaratarán la convivencia, base a su vez de la oración y los votos, arruinando al fin el carisma monástico. Por supuesto, no se trataría de una igualdad exacta o bruta sino de una igualdad proporcionada o equidad. Como una madre no dará igual trozo de tarta al hijo de cuatro años que al de catorce, las cosas comunes se manejarían "no con criterios de igualdad porque no tenéis todos idéntica salud, sino conforme a la necesidad de cada cual" ${ }^{46}$.

El monacato compondrá desde el primer momento un clamor silencioso por la igualdad social. Las hermanas de san Antonio, san Pacomio y san Agustín testimonian monasterios femeninos simultáneos a los masculinos; las hermandades de san Basilio y san Agustín aunaron sacerdotes y seglares; las diferencias entre adinerados y míseros quedaban suprimidas al ingresar en el cenobio... ${ }^{47}$ Podría parafrasearse a san Pablo: ya no hay ni rico ni pobre, ni clérigo ni laico, ni hombre ni mujer, pues todos son uno en el ideal monástico.

La fraternidad monacal conllevará igualmente perdurables estructuras democráticas. Si la democracia asamblearia nació en la Grecia clásica y la democracia representativa se organizó en la Gran Bretaña del siglo XVII, el monaquismo podría considerarse el eslabón perdido (y tan perdido, nadie se lo reconoce). Efectivamente, parten de una reglamentación común asumida por todos llamada Regla, que es actualizada y aprobada entre todos mediante unas Constituciones; eligen por votación secreta a sus superiores, vitaliciamente a los primeros abades, con mandato limitado a los priores; y resuelven las cuestiones comunitarias mediante capítulos decisorios, con voz y voto para todos, ejecutados por los superiores y sus consejos. Constituciones nacionales, elecciones periódicas, parlamentos legislativos... ¿no son precisamente la esencia de la democracia?

Sin embargo, la evolución histórica generará graves desigualdades en los muros del monasterio, corroboradas institucionalmente. La tradición

${ }^{46}$ SAn Agustín, Regla 4, citando luego Hch 4,32.35: "tenían todo en común y se distribuía a cada uno según su necesidad".

${ }^{47}$ San Atanasio, Vida de Antonio 3,1; San Agustín, Regla 16-18. 
benedictina empezó a distinguir a partir del II milenio entre clérigos: monjes sacerdotes dedicados al oficio divino, el estudio en la biblioteca y la pastoral de sus iglesias, y conversos: monjes laicos, de origen penitente e inculto, encargados de la administración y el trabajo manual en las posesiones de abadías y prioratos, según las capacidades de cada cual. Esto se alargará a las monjas y mendicantes, añadiéndose a ello la diversa procedencia nobiliaria o plebeya. La distancia entre ambos se irá agrandando, cada parte desligada de las obligaciones de la otra, unos alcanzando alta formación y otros permaneciendo bastos e iletrados (legos), con distintas salas comunes en el convento, como los compartimentos de $1^{\mathrm{a}}$ y $2^{\mathrm{a}}$ clase de trenes y aviones. El Vaticano II pedirá superar estas distorsiones y reencontrar la inspiración original. "Para que el vínculo de hermandad sea más íntimo, los llamados conversos, coadjutores o con otro nombre se unan estrechamente a la vida y obras de la comunidad (...) y que en los institutos de mujeres se llegue a una sola clase de hermanas (...) todos en igualdad de condiciones, derechos y deberes" (PC 15).

Otra renovación interna del espíritu comunitario incidirá en la comprensión de la autoridad desde el "espíritu de servicio a los hermanos", abominando del abuso de poder y la humillación, resaltando el "respeto a la persona humana". Atrás van a quedar los tiempos del ordeno y mando monacal, que en su versión oficial conminaba en virtud de santa obediencia. Ahora se sugiere fomentar más bien decisiones colegiales, a través de "los capítulos y consejos". Paralelamente, la obediencia es entendida como "sumisión voluntaria", esto es, "obediencia activa y responsable" (PC 14). Ser superior en época preconciliar de obediencia ciega era todo un honor, como recibir un cheque en blanco; serlo ahora en la modernidad de la obediencia dialogada es un quebradero de cabeza, te dan las gracias por aceptar el cargo. Pero qué duda cabe que es también una adecuada acomodación a los signos de los tiempos.

\section{LAUS DEO}

El concilio pidió a todos los institutos de vida consagrada una reforma profunda, de arriba abajo. "Se revisarán las constituciones, directorios, libros de costumbres, preces y ceremonias y otros códigos por el estilo, y suprimiendo las ordenaciones que resulten anticuadas se adaptarán a los documentos de este sagrado concilio" (PC 3). Sonaba casi a la preparación penitencial que exige dolor de los pecados y propósito de la enmienda. Pero 
un escuadrón obediente como el que conforman los religiosos no iba a hacer menos. Apenas terminó el sínodo ecuménico se fueron convocando capítulos generales especiales, renovando constituciones y estatutos, actualizando modos y costumbres. Los temas considerados y debatidos reflejaban el núcleo de la vida religiosa: carisma fundacional, vida de oración, consejos evangélicos, vida comunitaria, apostolado. En pro del acercamiento al mundo los institutos de vida apostólica y acción social han aprobado grandes cambios: aminoración del rezo, reinterpretación de la obediencia, relajación de la clausura; (des)vestición del hábito; formación espiritual, social y técnica; fundación, adecuación, supresión, federación de nuevos y antiguos institutos, todo "acomodado a las circunstancias de tiempos y lugares", como se repite machaconamente (PC 16-22). Los cambios no han sido fáciles, y sí muchas veces dolorosos, llenos de rupturas, decepciones y defecciones. Pero toda esa labor progresiva a lo largo de los años posteriores constituye ahora "uno de los frutos importantes del concilio"48.

La aportación al mundo y a la Iglesia de los institutos de vida consagrada y sociedades de vida apostólica es impagable, ilimitada, incesante (modestia aparte en la infinitésima que me toque). Siendo su meta la mística (la búsqueda de Dios) y su camino la ascética (las renuncias votivas), son un necesario recordatorio escatológico: la relatividad de las cosas, la temporalidad del tiempo. No sólo abarcan todos los ámbitos posibles de la presencia eclesial -de la contemplación y oración altruista, al apostolado pastoral y misionero, pasando por la promoción humana y social-, sino que lo han hecho de modo vanguardista y arriesgado -en las fronteras de la misión, en las periferias marginales, en los límites de la interioridad-, a lo largo de la geografía y la historia -de la construcción de Europa a la evangelización de América, de la inculturación en Asia a la exploración de África-. Han inventado, difundido o comandado la agropecuaria, arquitectura, artesanía y bibliotecaria en el I milenio; la universidad, los estudios, la pastoral y la fraternidad en la $1^{\text {a }}$ mitad del II; y las misiones, hospitales, escuelas y asilos en la $2^{\mathrm{a}}$ mitad. Además de encabezar la continuación de la democracia, la abolición de la esclavitud y la emancipación de la mujer. ¿Alguien da más? (Se ve que como Pablo -2Cor 11,16ss- no tenemos abuela.) Ciertamente, no todo lo habrán hecho de modo limpio y positivo, incluso habrán dibujado muchos rasgos de injusticia, colaborando en conquistas y colonialismos, fosilizando desigualdades internas y externas, no dejan de ser

${ }^{48} \mathrm{M}$. Dortel-Claudot, La labor de revisión de las constituciones de los Institutos de vida consagrada pedida por el Vaticano II: Latourelle 861s. 
"pobre barro en manos del alfarero" (Jer 18,4). Los modos habrán podido ser muchas veces erróneos, inhumanos, pero los fines han sido siempre cristianos, humanizadores. En cualquier caso, modestos y sacrificados, como les modelan sus votos, no les va a importar que nadie miente sus méritos, no los van a reivindicar. Fieles a su carisma se mantendrán alejados del mundo, concordarán en que "sólo Dios basta", como zanjó la ilustre carmelita.

La actual escasez de vocaciones es una de las angustias de las congregaciones de vida consagrada. Capítulos, consejos, convivencias, retiros, programas... se preguntan qué hacer, qué está fallando, si está desfasada la estrategia, si están abocados a la extinción. En realidad, la crisis vocacional de la vida religiosa es parte de una más amplia y moderna crisis de fe. El desencantamiento del mundo, la descristianización de Occidente, la secularización social, la nueva evangelización... son conceptos académicos devenidos tópicos de uso común. Estamos en un fin de ciclo, vivimos un cambio de paradigma... imposible que no nos haya pillado a contrapié. Formando parte de la médula espinal de la Iglesia, no podrá haber vida consagrada sin vivencia de la fe. Si la fe tiene futuro, como creemos, lo tendrán también las instituciones de vida consagrada. El concilio responde a la cuestión sencillamente, certeramente, expresando lo que todos, quién más, quién menos, hace tiempo han intuido: "recuerden los religiosos que el ejemplo de su vida es la mejor recomendación de su instituto y una invitación a abrazar la vida religiosa" (PC 24). 